\title{
Feeding habits of the Mexican barracuda, Sphyraena ensis Jordan and Gilbert, 1882 , in the southeastern end of the Gulf of California
}

\section{Hábitos alimentarios de la barracuda mexicana, Sphyraena ensis Jordan y Gilbert, 1882, en el extremo sureste del golfo de California}

\author{
Xchel Gabriel Moreno-Sánchez ${ }^{1}$, Deivis Samuel Palacios-Salgado ${ }^{2 \dagger}$, Jasmin Granados-Amores ${ }^{2}$, \\ Leonardo Andrés Abitia-Cárdenas ${ }^{1 *}$, Ofelia Escobar-Sánchez ${ }^{3}$ \\ ${ }^{1}$ Instituto Politécnico Nacional (IPN), Centro Interdisciplinario de Ciencias Marinas, Av. Instituto Politécnico \\ Nacional, s/n, Col. Playa Palo de Santa Rita, CP 23096, La Paz, Baja California Sur, Mexico. \\ 2 Escuela Nacional de Ingeniería Pesquera, Universidad Autónoma de Nayarit, Bahía de Matanchén, km 12, \\ Carretera a los Cocos, CP 63740, San Blas, Nayarit. Mexico. \\ ${ }^{3}$ Universidad Autónoma de Sinaloa (UAS), Facultad de Ciencias del Mar (FACIMAR), Paseo Claussen S/N, \\ Colonia Los Pinos, CP 82000, Mazatlán, Sinaloa, Mexico.
}

* Corresponding author. E-mail: laabitia@gmail.com

\begin{abstract}
Understanding the feeding habits of the Mexican barracuda, Sphyraena ensis Jordan and Gilbert, 1882, is important to elucidate relevant aspects of its trophic ecology (prey intake, diet breadth, trophic level, and energy flows), which in general provide valuable information on the dynamics of marine communities. Therefore, the purpose of this work was to assess the dietary habits of the Mexican barracuda, S. ensis, and to determine dietary variations by sex (males, females), size (small, medium, and large individuals), and season (rainy and dry). Monthly samples were obtained from February 2014 to January 2015 in the San Blas region, Nayarit, Mexico. A total of 308 specimens were captured. Individuals measured between 30.6 and $58.7 \mathrm{~cm}$ total length and weighed between 405 and $836 \mathrm{~g}$. Of the analyzed stomachs, 264 (86\%) contained food and 44 (14\%) were empty. The diet of the Mexican barracuda comprised 13 prey items from 11 families, 12 genera, and 9 species. According to the index of relative importance, the most important prey were fishes, particularly Sardinops spp. (40.36\%), Hemiramphus saltator (40.24\%), Opisthopterus dovii (10.83\%), Anchoa spp. (4.17\%), and Mugil cephalus (3.05\%). We conclude that the Mexican barracuda can be categorized as an opportunistic ichthyophagous predator in coastal epipelagic zones that feeds mainly on schooling fish species. The trophic spectrum did not vary significantly by sex or size, but the consumption of preferred prey varied significantly by season.
\end{abstract}

Key words: Sphyraenidae, pelagic predator, ichthyophagous, Sardinops spp., Hemiramphus saltator.

RESUMEN. El estudio de los hábitos alimentarios de la barracuda mexicana, Sphyraena ensis Jordan y Gilbert, 1882, es importante para conocer los aspectos relevantes de su ecología trófica (presas consumidas, amplitud de dieta, nivel trófico y flujos de energía), ya que brindan información valiosa sobre la dinámica de las comunidades marinas. En este contexto, el objetivo del presente trabajo fue determinar los hábitos alimentarios de la barracuda mexicana, S. ensis, así como las variaciones tróficas con respecto a sexo (machos, hembras), tallas (individuos pequeños, medianos y grandes) y estacionalidad (lluvias y secas). Se obtuvieron muestras mensuales durante el periodo de febrero de 2014 a enero de 2015 en la región de San Blas, Nayarit, México. En total se capturaron 308 organismos, con tallas de entre 30.6 y $58.7 \mathrm{~cm}$ de longitud total y pesos de entre 405 y 836 g. De los estómagos analizados, 264 (86\%) contenían alimentos y 44 (14\%) estaban vacíos. El espectro trófico de la barracuda mexicana se conformó de 13 tipos de presa, agrupadas en 11 familias, 12 géneros y 9 especies. De acuerdo con el índice de importancia relativa, las presas más importantes fueron los peces, particularmente Sardinops spp. (40.36\%), Hemiramphus saltator (40.24\%), Opisthopterus dovii (10.83\%), Anchoa spp. (4.17\%) y Mugil cephalus (3.05\%). Con base en los resultados obtenidos, la barracuda mexicana puede categorizarse como un depredador ictiófago oportunista de la zona epipelágica costera que se alimenta, principalmente, de especies de peces que forman densos cardúmenes. Su espectro trófico no presentó variaciones significativas por sexo y talla, pero el consumo de las presas más importantes varió significativamente por estación.

Palabras clave: Sphyraenidae, depredador pelágico, ictiófago, Sardinops spp., Hemiramphus saltator.

\section{INTRODUCTION}

Barracudas (Sphyraenidae) are carnivorous predators that affect the behavior and recruitment of the species they prey on and, as such, function as regulators of fish communities in coastal areas (Barreiros et al. 2002, Hooker et al. 2007, Mohammadizadeh et al. 2010). There are

\section{INTRODUCCIÓN}

Las barracudas (Sphyraenidae) son depredadores carnívoros que afectan el comportamiento y reclutamiento de sus presas y, como tal, funcionan como reguladores de las comunidades de peces en las zonas costeras (Barreiros et al. 2002, Hooker et al. 2007, Mohammadizadeh et al. 2010). 
27 barracuda species worldwide, all belonging to one genus, Sphyraena (Nelson et al. 2016). There are 5 barracuda species in the Gulf of California: the Pacific barracuda (Sphyraena argentea Girard, 1854), the Mexican barracuda (Sphyraena ensis Jordan and Gilbert, 1882), the pelican barracuda (Sphyraena idiastes Heller and Snodgrass, 1903), the Cortés barracuda (Sphyraena lucasana Gill, 1863), and the blackfin barracuda (Sphyraena qenie Klunzinger, 1870) (Robertson and Allen 2015). The most abundant barracuda species in the southeastern end of the Gulf of California is the Mexican barracuda, S. ensis, a pelagic/ neritic species that forms schools comprising several hundred individuals, although solitary individuals can also be found (Sommer 1995). Barracudas inhabit waters between 0 and $25 \mathrm{~m}$ deep, sandy, muddy bottoms, and rocky and coralline reefs near the coast (Sommer 1995, Robertson and Allen 2015).

The Mexican barracuda sustains a permanent fishery that is only interrupted during strong storms or hurricanes. This species is captured with several types of fishing gear (trolling lines, seine nets, gill nets, and handlines). Given the high quality of the flesh and low price, demand for this species is high in regional markets (Espino-Barr et al. 2003, Ulloa-Ramírez et al. 2008). Despite the ecological and economic importance of S. ensis, there is no published information on its basic ecology. Research on this species could include studies on food intake, diet composition, diet breadth, diet overlap, trophic levels, energetic physiology, and ecosystem-wide management (Pauly and Christensen 2000, Abitía-Cárdenas et al. 2002). All of these aspects can influence ecological characteristics such as growth, reproduction, and mortality of marine fish (Wootton 1998).

According to Zavala-Leal et al. (2018), previous biological studies on barracudas worldwide have mostly focused on feeding habits. Studies have included the trophic aspects of Sphyraena viridensis in the northeastern Atlantic Ocean (Barreiros et al. 2002), Sphyraena barracuda off Colombia (Hooker et al. 2007), Sphyraena putnamae in the Persian Gulf (Mohammadizadeh et al. 2010), and S. viridensis, Sphyraena sphyraena, and Sphyraena cryzotaenia in the Indo-Pacific Ocean (Kalogirou et al. 2012), among others. In Mexico, no studies on the trophic biology of the Mexican barracuda have been carried out. The only previous study was that of López-Peralta and Arcila (2002), who analyzed the stomach contents of 5 Mexican barracuda specimens caught in Colombian waters. These authors reported that Mexican barracuda fed on mainly nekton (fishes) and, in smaller portions, on zoobenthos (crustaceans).

In this context, we evaluated the dietary spectrum of the Mexican barracuda to determine possible diet variations with sex, size, and/or season. We provide basic information necessary to characterize the feeding interactions and, by extension, the role of this species in the energy flow of trophic webs in the coastal ecosystems of the southeastern end of the Gulf of California.
Existen 27 especies de barracudas en el mundo que constituyen un único género, Sphyraena (Nelson et al. 2016). Hay 5 especies de barracudas en el golfo de California: la barracuda plateada (Sphyraena argentea Girard, 1854), la barracuda mexicana (Sphyraena ensis Jordan y Gilbert, 1882), la barracuda pelicana, (Sphyraena idiastes Heller y Snodgrass, 1903), la barracuda de Cortés (Sphyraena lucasana Gill, 1863) y la barracuda aleta negra (Sphyraena qenie Klunzinger, 1870) (Robertson y Allen 2015). La especie más abundante de barracuda en el extremo sureste del golfo de California es la barracuda mexicana, S. ensis, una especie pelágica/nerítica que forma cardúmenes de varios cientos de individuos, aunque se pueden encontrar algunos individuos solitarios (Sommer 1995). Las barracudas habitan en aguas con profundidades de entre 0 y $25 \mathrm{~m}$, en fondos arenosos y lodosos, y en arrecifes rocosos y coralinos próximos a la costa (Sommer 1995, Robertson y Allen 2015).

La barracuda mexicana sostiene una pesquería permanente que solo es interrumpida durante fuertes tormentas o huracanes. Esta especie es capturada por medio de diversos tipos de artes de pesca (curricán, chinchorro playero, red de enmalle y línea de mano). Su alta demanda en los mercados regionales se debe a la alta calidad de su carne y al bajo precio (Espino-Barr et al. 2003, Ulloa-Ramírez et al. 2008). A pesar de la importancia ecológica y económica de S.ensis, no existen trabajos publicados con información sobre su ecología básica. La investigación sobre esta especie puede incluir estudios de su consumo de alimentos, la composición de su dieta, la amplitud de su dieta, los traslapes de su dieta, sus niveles tróficos, su fisiología energética y el manejo a nivel de ecosistemas (Pauly y Christensen 2000, Abitía-Cárdenas et al. 2002). Todos estos aspectos pueden influir en las características ecológicas como el crecimiento, la reproducción y la mortalidad de los peces marinos (Wootton 1998).

Zavala-Leal et al. (2018) indicaron que los trabajos previos sobre las barracudas alrededor del mundo se han centrado, principalmente, en sus hábitos alimentarios. Los estudios incluyen, entre otros, los aspectos tróficos de Sphyraena viridensis en el noreste del océano Atlántico (Barreiros et al. 2002), de Sphyraena barracuda en Colombia (Hooker et al. 2007), de Sphyraena putnamae en el golfo Pérsico (Mohammadizadeh et al. 2010) y de S. viridensis, Sphyraena sphyraena y Sphyraena cryzotaenia en el océano Indo-Pacífico (Kalogirou et al. 2012). No se han realizado estudios de la biología trófica de la barracuda mexicana en México. El único estudio previo es el López-Peralta y Arcila (2002), quienes analizaron el contenido estomacal de 5 especímenes de barracuda mexicana que fueron capturados en Colombia. Estos autores reportaron que la barracuda mexicana se alimenta principalmente del necton (peces) y, en menor medida, del zoobentos (crustáceos).

En este contexto, evaluamos el espectro trófico de la barracuda mexicana para determinar las posibles variaciones dietéticas con respecto al sexo, la talla y/o la estacionalidad. Proporcionamos la información básica necesaria para caracterizar las interacciones alimenticias y, por extensión, el rol de 
Moreno-Sánchez et al.: Feeding habits of the Mexican barracuda, Sphyraena ensis

\section{MATERIALS AND METHOdS}

Mexican barracuda specimens were obtained from the artisanal fishery in the San Blas region, Nayarit, Mexico $\quad\left(21^{\circ} 29^{\prime} 42.07^{\prime \prime}-21^{\circ} 26^{\prime} 47.47^{\prime \prime N}\right.$; $\quad 105^{\circ} 17^{\prime} 27.30^{\prime \prime}-$ $\left.105^{\circ} 13^{\prime} 43.88^{\prime \prime} \mathrm{W}\right)$ (Fig. 1). Fish were caught at night (19:00 to $06: 00$ ) using 5 - to 20 -m-long weighted handlines and J-type hooks (numbers 6 and 7). It should be noted that S. ensis can be caught using other types of fishing gear; however, off the coast of Nayarit, barracudas are caught mainly with handlines at night and in the early hours of the morning. According to artisanal fishermen, barracudas are not available during the day.

The habitat where organisms were captured is characterized by soft, sandy, muddy bottoms, with depths of 8.5-15.0 m. Sampling was carried out over an annual cycle (February 2014 to January 2015), catching approximately 30 fish per month. Specimens were frozen and transported to the Laboratorio de Ecología Trófica at the Escuela Nacional de Ingeniería Pesquera (Nayarit, Mexico), where biometric measurements (total length and weight with precision of $1 \mathrm{~mm}$ and $0.1 \mathrm{~g}$, respectively) were taken and stomachs collected.

Stomach contents were separated by taxonomic group, and each item was identified to the lowest taxonomic level possible. Depending on the digestion state of prey, fish taxonomic identification was carried out using the keys by Clothier (1950), Miller and Jorgensen (1973), and Fischer et al. (1995a, b). Crustaceans and mollusks were identified using the keys by Brusca (1980) and Morris et al. (1980).

A species accumulation curve was created with the program EstimateS Swin820 (Colwell 2009) using the ShannonWiener diversity index $\left(H^{\prime}\right)$ value obtained for each stomach to determine the representativeness of the number of analyzed stomachs. The coefficient of variation $(\mathrm{CV})$ was calculated to obtain a quantitative estimate of the number of stomachs representative of the diet. If the $\mathrm{CV}$ was equal to or less than $5 \%(0.05)$, the number of examined stomachs was considered adequate to represent the diet (Jiménez-Valverde and Hortal 2003, Moreno-Sánchez et al. 2015).

The frequency of occurrence $(\% \mathrm{FO})$, numerical $(\% \mathrm{~N})$, and gravimetric $(\% \mathrm{~W})$ percentages were calculated (Hyslop 1980) and used to estimate the index of relative importance (IRI) proposed by Pinkas et al. (1971) and modified by Hacunda (1981): IRI $=(\% \mathrm{~N}+\% \mathrm{~W}) \times \%$ FO . To facilitate comparisons with previous studies, the standardized version of the index (\%IRI) was also used (Cortés 1997): $\% \mathrm{IRI}_{i}=\left(100 \mathrm{IRI}_{i} / \sum_{i=1}^{n} \mathrm{IRI}_{I}\right)$.

In addition to the characterization of the general trophic spectrum, diets by sex (male or female), size, and season were also determined. Because size at maturity for the Mexican barracuda has not yet been determined and with the purpose of detecting a possible change in food intake (biomass) with size of organisms (total length), a cluster analysis esta especie en los flujos energéticos de las cadenas tróficas en los ecosistemas costeros del extremo sureste del golfo de California.

\section{Materiales Y MÉTOdOS}

Los especímenes de la barracuda mexicana se obtuvieron de la pesquería artesanal de la región de San Blas, Nayarit, México $\left(21^{\circ} 29^{\prime} 42.07^{\prime \prime}-21^{\circ} 26^{\prime} 47.47^{\prime \prime} \mathrm{N} ; \quad 105^{\circ} 17^{\prime} 27.30^{\prime \prime}-\right.$ $105^{\circ} 13^{\prime} 43.88^{\prime \prime} \mathrm{W}$ ) (Fig. 1). Lo peces fueron capturados durante la noche (19:00 a 06:00) usando líneas de mano de 5 a $20 \mathrm{~m}$ de largo con plomos y anzuelos tipo $\mathrm{J}$ (número $6 \mathrm{y}$ 7). Debe señalarse que se puede capturar S. ensis con otros tipos de instrumentos de pesca; sin embargo, frente a la costa de Nayarit, las barracudas se capturan, principalmente, con líneas de mano durante la noche y las primeras horas del día. Según los pescadores artesanales, no se encuentran barracudas durante el día.

El ambiente en el cual se capturaron los organismos presentó una profundidad de $8.5-15.0 \mathrm{~m}$ y se caracteriza por fondos suaves, arenosos y lodosos. El muestreo se llevó a cabo durante un ciclo anual (de febrero 2014 a enero 2015), y se capturaron aproximadamente 30 peces por mes. Los especímenes se congelaron y se transportaron al Laboratorio de Ecología Trófica en la Escuela Nacional de Ingeniería Pesquera (Nayarit, México), donde se tomaron las medidas biométricas (longitud total y peso con precisión de $1 \mathrm{~mm} \mathrm{y}$ $0.1 \mathrm{~g}$, respectivamente) y se recolectaron los estómagos.

Los contenidos estomacales fueron separados por grupo taxonómico, y cada ítem fue identificado al nivel taxonómico más bajo posible. Dependiendo del grado de digestión de las presas, la identificación taxonómica de los peces se llevó a cabo con las claves de Clothier (1950), Miller y Jorgensen (1973) y Fischer et al. (1995a, b). Los crustáceos y los moluscos fueron identificados con las claves de Brusca (1980) and Morris et al. (1980).

Se creó una curva de acumulación de especies con el programa EstimateS Swin820 (Colwell 2009) usando el valor del índice de diversidad de Shannon-Wiener $\left(H^{\prime}\right)$ obtenido para cada estómago para determinar la representatividad del número de estómagos analizados. El coeficiente de variación $(\mathrm{CV})$ se calculó para obtener un estimado cuantitativo del número de estómagos representativos de la dieta. Si el $\mathrm{CV}$ era igual a o menor que 5\% (0.05), el número de estómagos analizados se consideraba adecuado para representar la dieta (Jiménez-Valverde y Hortal 2003, Moreno-Sánchez et al. 2015).

El porcentaje de la frecuencia de ocurrencia $(\% \mathrm{FO})$ y los porcentajes numéricos $(\% \mathrm{~N})$ y gravimétricos $(\% \mathrm{~W})$ fueron calculados (Hyslop 1980) y utilizados para estimar el índice de importancia relativa (IIR) propuesto por Pinkas et al. (1971) y modificado por Hacunda (1981): IRI $=(\% \mathrm{~N}+\% \mathrm{~W}) \times \% \mathrm{FO}$. La versión estandarizada del índice (\%IIR) también se usó para facilitar las comparaciones con estudios previos (Cortés 1997): $\% \mathrm{IIR}_{i}=\left(100 \mathrm{IIR}_{i} / \sum_{i=1}^{n} \mathrm{IIR}_{I}\right)$. 


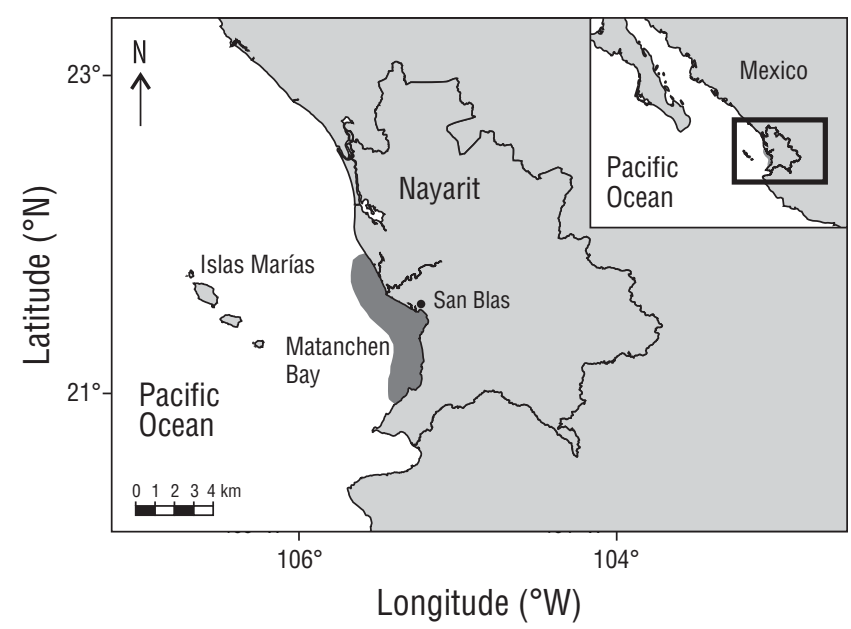

Figure 1. Map showing the Mexican barracuda, Sphyraena ensis, sampling area (shaded area) off San Blas, Nayarit, Mexico.

Figura 1. Mapa que muestra el área de muestreo de la barracuda mexicana, Sphyraena ensis, (área sombreada) frente a San Blas, Nayarit, México.

was performed using the program Primer v.6.0. The results obtained when we "let the data speak" consisted of a series of groups without a defined pattern. These groups comprised different size records with no logical trend; that is, there was no increase in prey biomass intake with the increase in predator size. Considering the above and to simplify the ontogenetic analysis, 3 groups based on total length were created (Sturges' rule, Daniel 1997): small $(30-39 \mathrm{~cm})$, medium $(40-49 \mathrm{~cm})$, and large $(50-60 \mathrm{~cm})$. In the case of the seasonal analysis, monthly precipitation over the study area was taken into account, and 2 seasons were identified: a rainy season from June to October and a dry season from November to May (CONAGUA 2013).

The breadth of the Mexican barracuda trophic spectrum was calculated with the absolute values of the numerical index using Levins' standardized index of niche breadth $\left(B_{i}\right)$ (Hurlbert 1978). Values for this index range from 0 to 1 ; values $<0.6$ indicate a diet that includes few prey items and corresponds to a specialist predator, and values $>0.6$ indicate that the diet includes several prey items and corresponds to a generalist predator (Krebs 1999). This index was calculated as $B_{i}=\frac{1}{n-1}\left(\frac{1}{\sum_{j} p_{i j}^{2}}-1\right)$, where $\sum_{j} p_{i j}^{2}$ is the proportion of the $j$ th prey species in the diet of predator $i$, and $n$ is the total number of prey species.

A scatter plot was constructed using the graphical method of Costello (1990) as modified by Amundsen et al. (1996) to interpret the Mexican barracuda's feeding strategy. These authors distinguished 4 strategies: (1) specialization on different types of prey, (2) a more generalized diet with some individual variation in diet breadth, (3) specialization on one type of prey while occasionally consuming other species, and (4) a mixed foraging strategy in which some individuals consume a specialized diet and others employ a more generalized
Además de la caracterización del espectro trófico general, también se determinaron las dietas con respecto al sexo (macho o hembra), la talla y la estación. Debido a que aún no se ha determinado la talla de madurez sexual de la barracuda mexicana, y con el propósito de detectar un posible cambio en la ingesta de alimentos (biomasa) con la talla de los organismos (longitud total), se realizó un análisis de grupos utilizando el programa Primer v.6.0. Los resultados que obtuvimos cuando "dejamos que los datos hablaran" consistieron en una serie de grupos sin ningún patrón definido. Estos grupos contenían registros de diferentes tallas sin una tendencia lógica; es decir, no hubo un aumento en la ingesta de biomasa de presas con el aumento de la talla del depredador. Considerando lo anterior y para simplificar el análisis ontogenético, se crearon 3 grupos basados en la longitud total (la regla de Sturges, Daniel 1997): talla pequeña (30-39 cm), mediana $(40-49 \mathrm{~cm})$ y grande $(50-60 \mathrm{~cm})$. Para el análisis estacional, se tomó en cuenta la precipitación mensual en el área de estudio, y se identificaron 2 estaciones: una estación de lluvias de junio a octubre y una estación seca de noviembre a mayo (CONAGUA 2013).

La amplitud del espectro trófico de la barracuda mexicana se calculó con los valores absolutos del índice numérico usando el índice estandarizado de Levins $\left(B_{i}\right)$ (Hurlbert 1978). Los valores para este índice varían de 0 a 1 ; los valores $<0.6$ indican una dieta compuesta por pocos tipos de presas que corresponde a un depredador especialista, y los valores $>0.6$ indican una dieta compuesta por varios tipos de presas que corresponde a un depredador generalista (Krebs 1999). Este índice se calculó como $B_{i}=\frac{1}{n-1}\left(\frac{1}{\sum_{j} p_{i j}^{2}}-1\right)$, donde $\sum_{j} p_{i j}^{2}$ es la proporción de la especie de la presa $j$ en la dieta del depredador $i, \mathrm{y} n$ es el número total de especies de presas.

Se construyó un diagrama de dispersión utilizando el método gráfico de Costello (1990) modificado por Amundsen et al. (1996) para interpretar la estrategia de alimentación de la barracuda mexicana. Estos autores distinguieron 4 estrategias: (1) especialista con diferentes tipos de presas, (2) una dieta más generalista con alguna variación individual en la amplitud de la dieta, (3) especialista con un tipo de presa y que ocasionalmente consume otras especies y (4) una estrategia de alimentación mixta en la que algunos individuos consumen una dieta especialista y otros emplean una estrategia de alimentación más generalista. El método Costello se usó como una técnica complementaria para corroborar la amplitud del nicho trófico porque permite identificar patrones de especialización de la población o dieta individual y probar diferencias significativas en la dieta.

Aplicamos un análisis de la varianza multivariado basado en permutaciones (PERMANDEVA, 1,000 permutaciones) a los datos numéricos obtenidos $(\mathrm{N})$ para poder evaluar las diferencias potenciales en la dieta de la barracuda con respecto al sexo (macho o hembra), la talla (pequeño, mediano o grande) y la estación (lluviosa o seca), y las posibles interacciones entre los factores. La matriz de disimilitud que se usó en la prueba PERMANDEVA se construyó calculando la 
foraging strategy. The Costello method was used as a complementary technique to corroborate trophic niche breadth because it allows identifying patterns of population specialization or individual diet, and testing for significant differences in the diet.

In order to assess potential differences in the diet of the barracuda as a function of sex (male or female), size (small, medium, or large), season (dry or rainy), and possible interactions between factors, we applied a permutation analysis of variance (PERMANOVA, 1,000 permutations) to the obtained numerical data $(\mathrm{N})$. The dissimilarity matrix used for the PERMANOVA test was constructed by calculating the Bray-Curtis dissimilarity distances matrix using the original data (no data transformation was used). Because some likelihood-based tests of differences in multivariate data can be sensitive to the heterogeneity of multivariate dispersion, we performed a PERMDISP analysis (Anderson 2006) to assess potential differences in dispersion among factors (sex, size, and season); PERMDISP can be used as a multivariate analogue of Levene's test for homogeneity of variances (Anderson 2006, Oksanen et al. 2016). We used the betadisp and adonis functions for the PERMDISP and PERMANOVA tests, respectively, using a significance level of $95 \%$; both functions belong to the Vegan package (v.2.4-1, Oksanen et al. 2016) in the R environment ( $\mathrm{R}$ Core Team 2016).

The equation proposed by Cortés (1999) was used to determine the trophic level of the Mexican barracuda $\left(T L_{k}\right)$, which considers the type of prey found in stomach contents: $T L_{k}=1+\left(\sum_{j=1}^{11} P_{j} \times T L_{j}\right)$, where $T L_{j}$ is the trophic level of the $j$ th prey and $P_{j}$ is the proportion of each prey item in the diet. The trophic level of each prey item was obtained from Cortés (1999), López-García et al. (2012), and Froese and Pauly (2016). Numerical data were used for these analyses.

\section{Results}

A total of 308 Mexican barracuda were obtained, ranging between 30.6 and $58.7 \mathrm{~cm}$ total length and between 405 and 836 g. Of the analyzed stomachs, $264(86 \%)$ contained food and $44(14 \%)$ were empty. According to the CV $(\leq 0.05)$, the prey species accumulation curve reached its asymptote at 85 stomachs, indicating that the total number of analyzed stomachs was adequate for the characterization of the feeding habits of the Mexican barracuda and the characterization of the diet by sex, size, and season (Fig. 2, Table 1).

The diet of the Mexican barracuda comprised 13 prey items, including 9 fish, 2 squid, and 2 shrimp species, and unidentified fish remains. Stomach contents weighed $951.35 \mathrm{~g}$ in total and included 273 prey items, of which fishes comprised $885.00 \mathrm{~g}$ and 235 prey items. The most frequent species in the diet were the fishes Sardinops spp. (Hubbs, 1929) (26.8\%, $n=73$ ), Hemiramphus saltator (Gilbert and Starks, 1904) $(25.7 \%, n=71)$, and Opisthopterus dovii (Günther, 1868) $(12.8 \%, n=37)$. According to the \%IRI, the most important prey species in the Mexican barracuda diet were matriz de distancias de disimilitud de Bray-Curtis usando los datos originales (no se realizó una transformación de datos). Debido a que algunas pruebas de diferencias en los datos multivariados basadas en la verosimilitud pueden ser sensibles a la heterogeneidad de la dispersión multivariada, realizamos un análisis PERMDISP (Anderson 2006) para evaluar las diferencias potenciales en la dispersión entre factores (sexo, talla y estación); la prueba PERMDISP puede ser usada como un análogo multivariante de la prueba de Levene para la homogeneidad de varianzas (Anderson 2006, Oksanen et al. 2016). Usamos las funciones betadisp y adonis para las pruebas PERMDISP y PERMANDEVA, respectivamente, con un nivel de significación del $95 \%$; ambas funciones pertenecen al paquete Vegan (v.2.4-1, Oksanen et al. 2016) en el ambiente R (R Core Team 2016).

Se utilizó la ecuación propuesta por Cortés (1999) para determinar el nivel trófico de la barracuda mexicana $\left(N T_{k}\right)$. Esta ecuación considera el tipo de presa encontrada en el contenido estomacal: $N T_{k}=1+\left(\sum_{j=1}^{11} P_{j} \times N T_{j}\right)$, donde $N T_{j}$ es el nivel trófico de la presa $j$ y $P_{j}$ es la proporción de cada tipo de presa en la dieta. Se determinó el nivel trófico de cada presa usando la información proporcionada por Cortés (1999), López-García et al. (2012) y Froese y Pauly (2016). Se utilizaron los datos numéricos para estos análisis.

\section{Resultados}

En total, se capturaron 308 barracudas mexicanas con tallas de entre 30.6 y $58.7 \mathrm{~cm}$ de longitud total y pesos de entre 405 y 836 g. De los estómagos analizados, 264 (86\%) contenían alimento y $44(14 \%)$ estaban vacíos. De acuerdo con el CV $(\leq 0.05)$, la curva de acumulación de especies de presas alcanzó su asíntota en 85 estómagos, lo cual indicó que el número total de estómagos analizados era adecuado para caracterizar los hábitos alimentarios de la barracuda mexicana y para caracterizar la dieta con respecto al sexo, la talla y la estación (Fig. 2, Tabla 1).

La dieta de la barracuda mexicana se conformó de 13 tipos de presas, incluyendo 9 especies de peces, 2 de calamar y 2 de camarón, y algunos restos de pescados no identificados. Los contenidos estomacales pesaron $951.35 \mathrm{~g}$ en total e incluyeron 273 ítems presa, de los cuales $885.00 \mathrm{~g}$ y 235 ítems eran de pescado. Las especies más frecuentes de la dieta fueron los peces Sardinops spp. (Hubbs, 1929) $(26.8 \%, n=73)$, Hemiramphus saltator (Gilbert y Starks, 1904) $(25.7 \%, n=71)$ y Opisthopterus dovii (Günther, 1868) $(12.8 \%, n=37)$. De acuerdo con el \%IIR, las especies de presas más importantes en la dieta de la barracuda mexicana fueron los peces Sardinops spp. (40.36\%), H. saltator (40.24\%), O. dovii (10.83\%), Anchoa spp. (4.17\%) y Mugil cephalus (3.05\%) (Fig. 3a, Tabla 2).

De los 264 estómagos que contenían alimento, 91 fueron extraídos de machos y 173 de hembras. La dieta de los machos se conformó de 10 ítems presa, mientras que la dieta de las hembras se conformó de 13 ítems. Según el \%IIR, las 


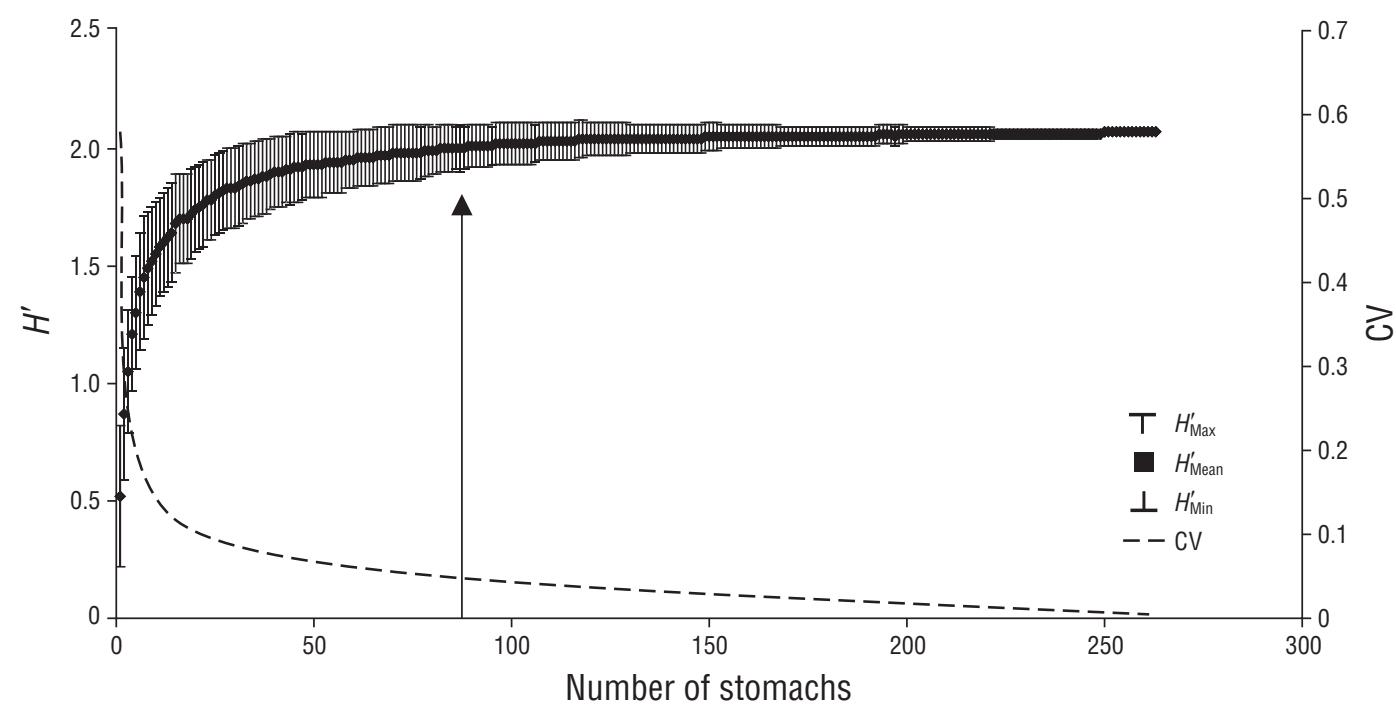

Figure 2. Species accumulation curve of Sphyraena ensis prey. The upward arrow indicates the asymptote of the curve. $H^{\prime}$, Shannon-Wiener diversity; $H_{\text {Max }}^{\prime}$, maximum diversity; $H_{\text {Mean }}^{\prime}$, mean diversity; $H_{\text {Min }}^{\prime}$, minimum diversity; and $\mathrm{CV}$, coefficient of variation.

Figura 2. Curva de acumulación de las especies de las presas de Sphyraena ensis. La flecha hacia arriba indica la asíntota de la curva. $H^{\prime}$, diversidad de Shannon-Wiener; $H_{\text {Max }}^{\prime}$, máxima diversidad; $H_{\text {Mean }}^{\prime}$, diversidad promedio; $H_{\text {Min }}^{\prime}$, diversidad mínima; y CV, coeficiente de variación.

the fishes Sardinops spp. (40.36\%), H. saltator $(40.24 \%)$, O. dovii (10.83\%), Anchoa spp. (4.17\%), and Mugil cephalus (3.05\%) (Fig. 3a, Table 2).

Of the 264 stomachs containing food, 91 were extracted from males and 173 from females. The male diet comprised 10 prey items, whereas the female diet included 13 items. According to the \%IRI, the most important prey for both sexes were H. saltator and Sardinops spp. (Fig. 3b, c). There were no significant differences in trophic spectra between males and females (PERMANOVA $F=13.514, P>0.05$ ) (Table 3 ).

There were 62 small-sized specimens, which fed on 10 prey items. According to the \%IRI, the most important prey in this group's diet were the fishes $H$. saltator (48\%), Sardinops spp. (24\%), O. dovii (14\%), Mugil cephalus (Linnaeus, 1758) (6\%), Anchoa spp. (Jordan and Evermann, 1927) (5\%), and other prey (0.84\%) (Fig. 3d). There were 158 medium-sized fish, which fed on 12 prey items. The diet of this group comprised mainly fish, of which the most important, according to the \%IRI, were $H$. saltator (51\%), Sardinops spp. (35\%), O. dovii (6\%), Anchoa spp. (3\%), M. cephalus (3\%), and other prey (1.61\%) (Fig. 3e). There were 44 large barracuda, which fed on 8 prey items. The most important prey in this group's diet were Sardinops spp. (67\%), O. dovii (21\%), H. saltator (6\%), Anchoa spp. (3\%), and other prey (0.04\%) (Fig. 3f). There were no significant differences in diets between size categories (PERMANOVA $F=14.468, P>0.05)($ Table 3$)$.

A total of 158 stomachs collected in the dry season and 106 stomachs collected in the rainy season were analyzed. During the dry season, the diet comprised 10 prey items; according to the \%IRI the most important prey were presas más importantes para ambos sexos fueron $H$. saltator y Sardinops spp. (Fig. 3b, c). No hubo diferencias significativas en los espectros tróficos entre los machos y las hembras (PERMANDEVA $F=13.514, P>0.05$ ) (Tabla 3 ).

Del total, 62 especímenes fueron pequeños y se alimentaron de 10 ítems presa. De acuerdo con el \%IIR, las presas más importantes en la dieta de este grupo fueron los peces H. saltator (48\%), Sardinops spp. (24\%), O. dovii (14\%), Mugil cephalus (Linnaeus, 1758) (6\%), Anchoa spp. (Jordan y Evermann, 1927) (5\%) y otras presas (0.84\%) (Fig. 3d). Encontramos 158 peces de talla mediana que se alimentaron de 12 ítems presa. La dieta para este grupo se conformó principalmente de peces, de los cuales los más importantes, de acuerdo con el $\%$ IIR, fueron $H$. saltator (51\%), Sardinops spp. (35\%), O. dovii (6\%), Anchoa spp. (3\%), M. cephalus (3\%) y otras presas (1.61\%) (Fig. 3e). Las barracudas que correspondieron a la talla grande fueron 44 , y se alimentaron de 8 ítems presa. Las presas más importantes en la dieta de este grupo fueron Sardinops spp. (67\%), O. dovii (21\%), H. saltator (6\%), Anchoa spp. (3\%) y otras presas (0.04\%) (Fig. 3f). No se observaron diferencias significativas entre los grupos de tallas (PERMANDEVA $F=14.468, P>0.05$ ) (Tabla 3 ).

Se analizaron 158 estómagos recolectados durante la estación seca y 106 recolectados durante la estación de lluvias. Durante la estación seca, la dieta incluyó 10 ítems presa; de acuerdo con el \%IIR, las presas más importantes fueron Sardinops spp. (71\%), O. dovii (11\%), Anchoa spp. (10\%) y H. saltator (4\%), y el resto de los ítems presa solo correspondieron al 4\% de la dieta (Fig. 3g). Durante la estación de lluvias, la dieta incluyó 8 ítems presa; las presas principales, de acuerdo con el \%IIR, fueron $H$. saltator (84\%), Sardinops spp. 
Sardinops spp. (71\%), O. dovii (11\%), Anchoa spp. (10\%), and $H$. saltator $(4 \%)$, and the remaining items comprised only $4 \%$ of the diet (Fig. 3g). During the rainy season, the diet comprised 8 items; the main prey, according to the \%IRI, were H. saltator (84\%), Sardinops spp. (5\%), O. dovii (4\%), M. cephalus (3\%), and Lutjanus spp. (Bloch 1790) (1\%) (Fig. 3h). Significant differences were observed between seasons (PERMANOVA $F=184.66, P<0.05$ ) and in the interactions between sex and season (PERMANOVA $F=14.488$, $P<0.05$ ) (Table 3 ). The dispersions of the Bray-Curtis dissimilarities were not statistically different for any of the analyzed factors $(F$ : $\operatorname{sex}=0.6537$, size $=0.7452$, season $=1.4383$; $P:$ sex $=0.4195$, size $=0.4756$, season $=0.2315$ ).

The Mexican barracuda can be categorized as a specialist predator $\left(B_{i}=0.34\right)$. This feeding behavior was consistent for males and females (males: $B_{i}=0.37$; females: $B_{i}=0.36$ ), for the 3 size intervals (small: $B_{i}=0.38$; medium: $B_{i}=0.36$; large: $B_{i}=0.48$ ), and for the 2 analyzed seasons (dry: $B_{i}=$ 0.41 ; rainy: $B_{i}=0.39$ ). The feeding strategy confirmed that the Mexican barracuda is a specialist predator (ichthyophagous) that consumes mainly the fishes H. saltator, Sardinops spp., Anchoa spp., O. dovii, M. cephalus, and Lutjanus spp. (Fig. 4). The trophic level calculated for S. ensis and for each sex was 4.1. Small-sized individuals occupied a trophic level of 4.0, medium-sized individuals a trophic level of 4.1, and large-sized individuals a trophic level of 4.0. The trophic level during the rainy season was 4.2 , and during the dry season, it was 3.9.

\section{DiSCUSSION}

Mexican barracuda fed mainly on the fishes Sardinops spp., H. saltator, O. dovii, and Anchoa spp. These are all small

Table 1. Minimum Sphyraena ensis sample size for all samples by sex, by size, and by season. Ns, number of analyzed stomachs; Nsm, minimum number of stomachs by category; CV, coefficient of variation for the respective sample size.

Tabla 1. Tamaño mínimo de muestra de Sphyraena ensis para todas las muestras, con respecto a sexo, talla y estación. Ns, número de estómagos analizados; Nsm, número mínimo de estómagos por categoría; $\mathrm{CV}$, coeficiente de variación para el tamaño de muestra respectivo.

\begin{tabular}{lrcl}
\hline Category & $\mathrm{N}_{\mathrm{s}}$ & $\mathrm{N}_{\mathrm{sm}}$ & $\mathrm{CV}$ \\
\hline General & 264 & 85 & 0.05 \\
Female & 173 & 60 & 0.05 \\
Male & 91 & 50 & 0.05 \\
Small & 62 & 30 & 0.05 \\
Medium & 158 & 60 & 0.05 \\
Large & 44 & 28 & 0.05 \\
Dry season & 158 & 63 & 0.05 \\
Rainy season & 106 & 46 & 0.05 \\
\hline
\end{tabular}

(5\%), O. dovii (4\%), M. cephalus (3\%) y Lutjanus spp. (Bloch 1790) (1\%) (Fig. 3h). Se observaron diferencias significativas entre las estaciones (PERMANDEVA $F=184.66$, $P<0.05)$ y en las interacciones entre los sexos y las estaciones (PERMANDEVA $F=14.488, P<0.05$ ) (Tabla 3). Las dispersiones de las disimilitudes de Bray-Curtis no fueron estadísticamente diferentes para ninguno de los factores analizados $(F:$ sexo $=0.6537$, talla $=0.7452$, estación $=1.4383 ; P:$ sexo $=$ 0.4195 , talla $=0.4756$, estación $=0.2315$ ) .

La barracuda mexicana puede ser catalogada como un depredador con el comportamiento alimentario de un especialista $\left(B_{i}=0.34\right)$. Este tipo de comportamiento alimentario fue consistente para los machos y las hembras (machos: $B_{i}=$ 0.37; hembras: $B_{i}=0.36$ ), los 3 intervalos de talla (pequeña: $B_{i}=0.38$; mediana $B_{i}=0.36$; grande: $\left.B_{i}=0.48\right)$ y las 2 estaciones analizadas (seca: $B_{i}=0.41$; lluviosa: $B_{i}=0.39$ ). $\mathrm{La}$ estrategia alimentaria confirmó que la barracuda mexicana es un depredador especialista (ictiófago) que se alimenta principalmente de los peces $H$. saltator, Sardinops spp., Anchoa spp., O. dovii, M. cephalus y Lutjanus spp. (Fig. 4). El nivel trófico calculado para S.ensis y para cada sexo fue de 4.1. Los individuos de talla pequeña ocuparon un nivel trófico de 4.0, los individuos de talla mediana un nivel trófico de 4.1 y los individuos de talla grande un nivel trófico de 4.0. Los niveles tróficos durante la estación de lluvias y durante la estación seca fueron 4.2 y 3.9, respectivamente.

\section{Discusión}

La barracuda mexicana se alimentó principalmente de los peces Sardinops spp., H. saltator, O. dovii y Anchoa spp. Estas especies son pequeñas y pelágicas/neríticas que se encuentran en cardúmenes a lo largo del océano Pacífico oriental, desde Baja California, incluyendo al golfo de California, hasta el norte del Perú e incluso Chile (Sommer 1995, Robertson y Allen 2015).

En general, la evidencia indica que las 5 especies de barracuda presentes a lo largo de las costas del Pacifico en México realizan un rol ecológico similar dentro de los límites de su distribución geográfica. Esto se debe a que las 5 especies de barracuda (S. ensis, S. argentea, S. lucasana, S. idiastes y $S$. qenie) son depredadores carnívoros que se alimentan principalmente de peces pequeños que forman cardúmenes en la zona pelágica-nerítica pero que pueden consumir crustáceos bénticos y cefalópodos (Sommer 1995, López-Peralta y Arcila 2002, Robertson y Allen 2015).

La estrategia alimentaria presentada por la barracuda mexicana corresponde a la de un especialista ictiófago. Este tipo de estrategia se ha reportado para S. viridensis, S. sphyraena y Sphyraena chrysotaenia en el mar Mediterraneo (Kalogirou et al. 2012), para S. barracuda en el archipiélago de San Andrés en Colombia (Hooker et al. 2007) y para Sphyraena guachancho en el golfo de México (Bedia-Sánchez et al. 2011). 

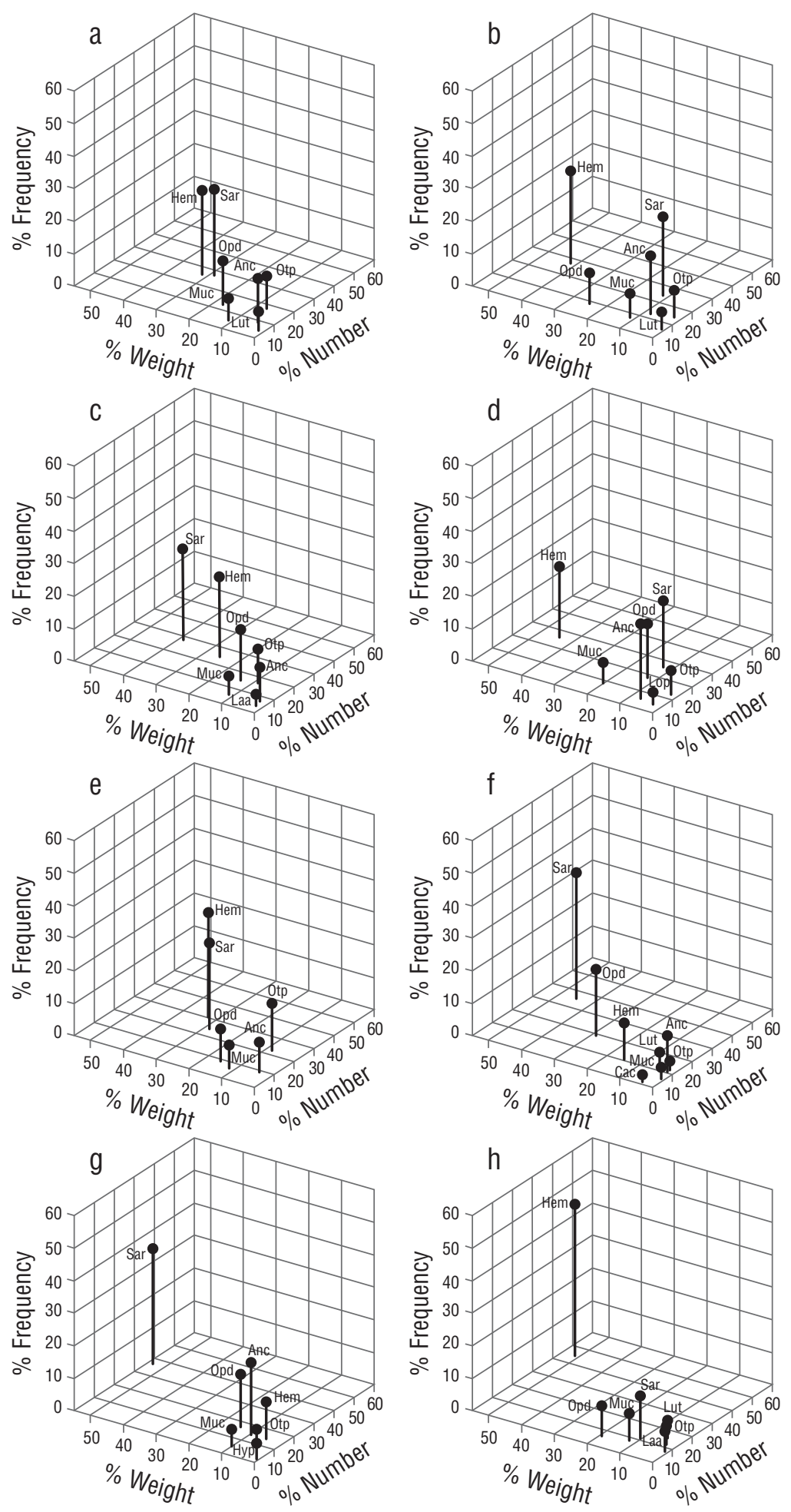

Figure 3. 3-D graphs showing trophic indices for prey consumed by Sphyraena ensis (number [abundance], weight [biomass], and frequency of occurrence). Data: general (a), males (b), females (c), small size (d), medium size (e), large size (f), dry season (g), rainy season (h). Abbreviations: Sar, Sardinops spp.; Hem, Hemiramphus saltator; Opd, Opisthopterus dovii; Anc, Anchoa spp.; Muc, Mugil cephalus; Lop, Lolliguncula panamensis; Hyp, Hyaloteuthis pelagica; Cac, Caranx caballus; Laa, Larimus argenteus; Lut, Lutjanus spp.; Otp, Other prey.

Figura 3. Gráficas tridimensionales que muestran los índices tróficos para las presas consumidas por Sphyraena ensis (número [abundancia], peso [biomasa] y frecuencia de ocurrencia). Datos: general (a), machos (b), hembras (c), talla pequeña (d), talla mediana (e), talla grande (f), estación seca (g), estación lluviosa (h). Abreviaturas: Sar, Sardinops spp.; Hem, Hemiramphus saltator; Opd, Opisthopterus dovii; Anc, Anchoa spp.; Muc, Mugil cephalus; Lop, Lolliguncula panamensis; Hyp, Hyaloteuthis pelagica; Cac, Caranx caballus; Laa, Larimus argenteus; Lut, Lutjanus spp.; Otp, Otras presas. 
Table 2. Absolute values, numerical percentage $(\% \mathrm{~N})$, weight percentage $(\% \mathrm{~W})$, frequency of occurrence percentage $(\% \mathrm{FO})$, index of relative importance (IRI), and trophic level (TL) for each food item in the diet of Sphyraena ensis.

Tabla 2. Valores absolutos, porcentaje numérico $(\% \mathrm{~N})$, porcentaje de peso $(\% \mathrm{~W})$, porcentaje de frecuencia de ocurrencia $(\% \mathrm{FO})$, índice de importancia relativa (IRI) y nivel trófico (TL) para cada ítem de alimento en la dieta de Sphyraena ensis.

\begin{tabular}{|c|c|c|c|c|c|c|c|c|c|}
\hline Species & $\mathrm{N}$ & $\% \mathrm{~N}$ & $\mathrm{~W}$ & $\% \mathrm{~W}$ & $\mathrm{FO}$ & $\% \mathrm{FO}$ & IRI & $\%$ IRI & $\mathrm{TL}$ \\
\hline \multicolumn{10}{|l|}{ Cephalopoda } \\
\hline \multicolumn{10}{|l|}{ Loliginidae } \\
\hline Lolliguncula panamensis & 4 & 1.47 & 7.90 & 0.83 & 4 & 1.52 & 3.48 & 0.09 & 3.90 \\
\hline \multicolumn{10}{|l|}{ Crustacea } \\
\hline \multicolumn{10}{|l|}{ Decapoda } \\
\hline \multicolumn{10}{|l|}{ Penaeidae } \\
\hline \multicolumn{10}{|l|}{ Actinopterygii } \\
\hline \multicolumn{10}{|l|}{ Carangidae } \\
\hline Caranx caballus & 5 & 1.83 & 17.20 & 1.81 & 4 & 1.52 & 5.51 & 0.15 & 3.40 \\
\hline \multicolumn{10}{|l|}{ Clupeidae } \\
\hline Sardinops spp. & 73 & 26.74 & 272.21 & 28.61 & 71 & 26.89 & 1488.66 & 40.36 & \\
\hline \multicolumn{10}{|l|}{ Engraulidae } \\
\hline Anchoa spp. & 37 & 13.55 & 39.10 & 4.11 & 23 & 8.71 & 153.88 & 4.17 & 3.40 \\
\hline \multicolumn{10}{|l|}{ Mugilidae } \\
\hline \multicolumn{10}{|l|}{ Lutjanidae } \\
\hline Lutjanus guttatus & 2 & 0.73 & 5.00 & 0.53 & 2 & 0.76 & 0.95 & 0.03 & 3.55 \\
\hline Lutjanus spp. & 10 & 3.66 & 3.80 & 0.40 & 8 & 3.03 & 12.31 & 0.33 & 3.55 \\
\hline \multicolumn{10}{|l|}{ Pristigasteridae } \\
\hline Opisthopterus dovii & 37 & 13.55 & 166.10 & 17.46 & 34 & 12.88 & 399.40 & 10.83 & 3.25 \\
\hline Fish Remains & 0 & 0 & 12.80 & 1.35 & 22 & 8.33 & 11.21 & 0.30 & \\
\hline Total & 273 & 100 & 951.35 & 100 & 264 & & 3688.83 & 100 & \\
\hline
\end{tabular}


Table 3. Significance values obtained with the permutational multivariate analysis of variance between sizes, sexes, and seasons for Sphyraena ensis in the southeastern end of the Gulf of California. Tabla 3. Valores de significación obtenidos con el análisis multivariado de la varianza basado en permutaciones entre tallas, sexos y estaciones para Sphyraena ensis en el extremo sureste del golfo de California.

\begin{tabular}{lrccc}
\hline Factor & \multicolumn{1}{c}{$F$} & $r$ & $P$ & Significance \\
\hline Size & 14.468 & 0.00508 & 0.206 & No \\
Sex & 13.514 & 0.00474 & 0.229 & No \\
Season & 184.661 & 0.06481 & 0.001 & Yes \\
Size-sex & 0.794 & 0.00279 & 0.545 & No \\
Size-season & 10.969 & 0.00385 & 0.353 & No \\
Sex-season & 37.768 & 0.01325 & 0.004 & Yes \\
Size-sex-season & 20.078 & 0.00705 & 0.058 & No \\
\hline
\end{tabular}

pelagic/neritic species that gather in schools and are distributed along the eastern Pacific Ocean, from Baja California, including the Gulf of California, to northern Peru and even Chile (Sommer 1995, Robertson and Allen 2015).

In general, evidence indicates that the 5 barracuda species found along the Pacific coast of Mexico play a similar ecological role within the limits of their geographical distribution, because the 5 species (S. ensis, S. argentea, S. lucasana, S. idiastes, and S. qenie) are carnivorous predators that feed mainly on small school-forming fish in the pelagic-neritic zone but can also consume benthic crustaceans and cephalopods (Sommer 1995, López-Peralta and Arcila 2002, Robertson and Allen 2015).

The Mexican barracuda has a specialist ichthyophagous feeding strategy. This type of strategy has been reported for S. viridensis, S. sphyraena, and Sphyraena chrysotaenia in the Mediterranean Sea (Kalogirou et al. 2012), for S. barracuda in the San Andrés Archipelago in Colombia (Hooker et al. 2007), and for Sphyraena guachancho in the Gulf of Mexico (Bedia-Sánchez et al. 2011).

No significant differences were detected between males and females or between sizes (small, medium, and large) in the diet of the Mexican barracuda due to the predominant consumption of the same fish species (Sardinops spp., $H$. saltator, O. dovii, Anchoa spp., and M. cephalus) in similar proportions. This trophic behavior indicated no feeding segregation by sex or size. However, large individuals fed on a larger proportion of Sardinops spp. These larger individuals probably have better search, attack, and capture abilities than smaller barracuda. Sardinops spp. are extremely abundant in the southern Gulf of California and in waters along the Pacific coast of Mexico (Fischer et al. 1995a).

According to the optimal foraging theory, feeding on small abundant fish would allow barracudas to obtain greater
No se detectaron diferencias significativas entre los machos y las hembras o entre las tallas (pequeña, mediana y grande) en la dieta de la barracuda mexicana debido al consumo predominante de las mismas especies de peces (Sardinops spp., H. saltator, O. dovii, Anchoa spp. y M. cephalus) en proporciones similares. Este comportamiento trófico indicó que no había una segregación alimenticia por sexo o talla. Sin embargo, los individuos de talla grande se alimentaron en una mayor proporción de Sardinops spp. Estos individuos de mayor talla, probablemente, presentan mejores habilidades de búsqueda, ataque y captura que las barracudas de menor talla. Sardinops spp. son extremadamente abundantes en el sur del golfo de California y a lo largo de la costa mexicana del Pacífico (Fischer et al. 1995a).

De acuerdo con la teoría del forrajeo óptimo, al alimentarse de peces pequeños y abundantes las barracudas pueden obtener mayores beneficios energéticos que al alimentarse de presas de mayor tamaño y menos disponibles que representan un mayor gasto energético durante la búsqueda, la captura y el consumo (Gerking 1994). Cabe destacar que la amplitud de la dieta de la barracuda mexicana aumentó con el tamaño, ya que la dieta de la barracuda más grande también incluía presas demersopelágicas (Carangidae, Lutjanidae y Mugilidae). Kalogirou et al. (2012) también reportaron que la amplitud de la dieta de $S$. viridensis, S. sphyraena y S. chrysotaenia aumentó con la talla, lo que podría relacionarse con que sus habilidades depredadoras mejoran conforme crecen.

Aunque los resultados de este estudio indicaron que la estrategia alimentaria era la de un especialista, las diferencias encontradas en la dieta de la barracuda mexicana entre las estaciones presentaron cambios en el consumo de Sardinops spp. (84\%) durante la estación seca y de H. saltator (71\%) durante la estación de lluvias. Esta alternación en la especie de la presa principal puede estar relacionada con las fluctuaciones naturales en la población de las especies de las presas. Aunque no existe información específica de las variaciones en la abundancia de las presas en el área de estudio, es probable que la barracuda mexicana deprede las especies más abundantes en la zona pelágico-nerítica, lo cual mejora la probabilidad de éxito alimentario durante todo el año. Esto indicaría que, en vez de ser un depredador especialista, la barracuda mexicana es un depredador ictiófago oportunista con una plasticidad trófica que le permite alimentarse de las especies de peces abundantes y disponibles. Bedia-Sánchez et al. (2011) y De Sylva (1963) reportaron que las barracudas S. guachancho y S. barracuda alternaron los principales componentes en su dieta dependiendo de las condiciones ambientales, las cuales afectaron la disponibilidad y abundancia de las especies de presas.

El nivel trófico calculado para la barracuda mexicana fue de 4.1. Esto es similar a lo reportado para otros depredadores ictiófagos con tendencias especialistas, como Xiphias gladius (Linnaeus, 1758) (4.5), Coryphaena hippurus (Linnaeus, 1758) (4.3), Fistularia commersonii (Rüppell, 1838) (4.3), 
energetic benefits than they would feeding on large, less available prey that would represent greater energy expenditure during the search, capture, and consumption (Gerking 1994). It should be noted that the diet breadth of the Mexican barracuda increased with size, as larger barracuda also included demerso-pelagic prey in their diet (Carangidae, Lutjanidae, and Mugilidae). Kalogirou et al. (2012) also reported that the diet breadth of S. viridensis, S. sphyraena, and S. chrysotaenia increased with size, which could be related to improved predatory abilities as they grow.

Although results obtained in this study indicated a specialist feeding strategy, differences found in the diet of the Mexican barracuda between seasons reflected changes in the consumption of Sardinops spp. (84\%) during the dry season and of $\mathrm{H}$. saltator $(71 \%)$ during the rainy season. This alternation of the main prey species could be related to the natural fluctuations in the populations of the prey species. Although no specific data on variations in prey abundance in the study area are available, it is probable that Mexican barracuda prey on the most abundant species in the pelagic-neritic zone, improving their chances of feeding success throughout the year. This would indicate that instead of being a specialist predator, the Mexican barracuda is an opportunistic ichthyophagous predator, with trophic plasticity that allows it to feed on available and abundant fish species. Bedia-Sánchez et al. (2011) and De Sylva (1963) reported that the barracudas $S$. guachancho and S. barracuda alternated the main food components in their diet according to environmental conditions, which affected the availability and abundance of prey species.

The trophic level calculated for the Mexican barracuda was 4.1. This is similar to what has been reported for other ichthyophagous predators with specialist tendencies, such as Xiphias gladius (Linnaeus, 1758) (4.5), Coryphaena hippurus (Linnaeus, 1758) (4.3), Fistularia commersonii (Rüppell, 1838) (4.3), Scomberomorus sierra (Jordan and Starks, 1895) (4.2), Thunnus albacares (Bonnaterre, 1788) (4.1), and Alectis ciliaris (Bloch, 1787) (4.0) (López-Peralta and Arcila 2002, Stergiou and Karpouzi 2002, Moreno-Sánchez et al. 2011, Tripp-Valdez et al. 2015, Froese and Pauly 2016, Alatorre-Ramirez et al. 2017), which also feed on schoolforming pelagic fishes and on cephalopods and crustaceans. It should be noted that the Mexican barracuda is part of the same trophic guild and interacts with these species in the ecosystems of the southern Gulf of California, which suggests possible interspecific competition. However, it seems that the availability and abundance of small pelagic fishes that form large schools (families Engraulidae and Clupeidae) (TrippValdez et al. 2015, Varela et al. 2017, Zambrano-Zambrano et al. 2019), in addition to the morphological differences of predators, allow these species to coexist without affecting their population densities (Cruz-Escalona et al. 2000, Moreno-Sánchez et al. 2015).

We conclude that the Mexican barracuda is an opportunistic ichthyophagous predator that does not present

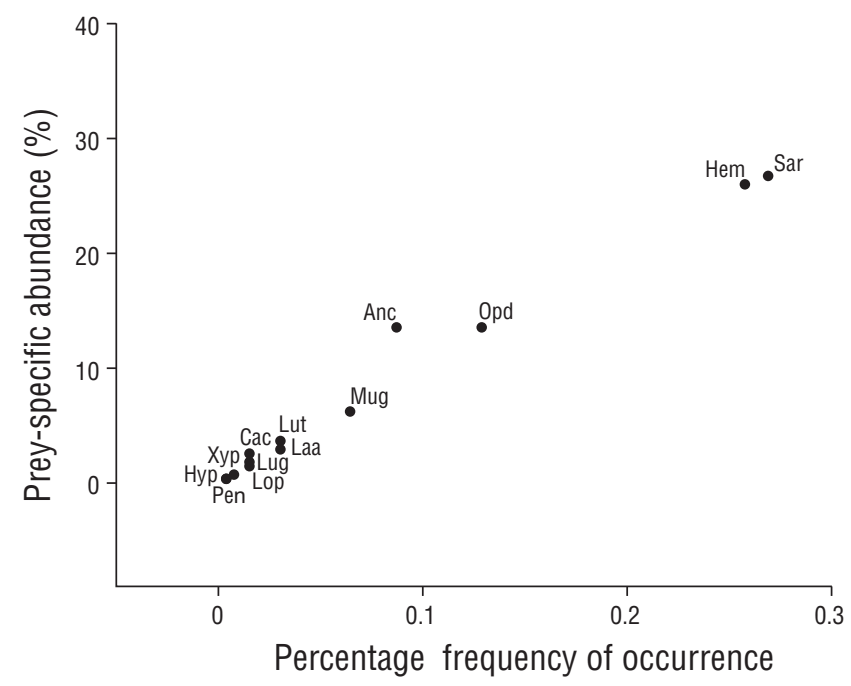

Figure 4. Feeding strategy graph obtained with the Costello method. Prey-specific abundance $(\% \mathrm{~N})$ and percentage frequency of occurrence $(\% \mathrm{~F})$ in the general diet of Sphyraena ensis. Abbreviations: Sar, Sardinops spp.; Hem, Hemiramphus saltator; Opd, Opisthopterus dovii; Anc, Anchoa spp.; Muc, Mugil cephalus; Lop, Lolliguncula panamensis; Hyp, Hyaloteuthis pelagica; Pen, Penaeus spp.; Xyp, Xyphopenaeus spp.; Cac, Caranx caballus; Laa, Larimus argenteus; Lug, Lutjanus guttatus; Lut $=$ Lutjanus spp.

Figura 4. Gráfica de la estrategia alimentaria obtenida con el método Costello. Abundancia presa-especifica $(\% \mathrm{~N})$ y porcentaje de frecuencia de ocurrencia $(\% \mathrm{~F})$ en la dieta general de Sphyraena ensis. Abreviaturas: Sar, Sardinops spp.; Hem, Hemiramphus saltator; Opd, Opisthopterus dovii; Anc, Anchoa spp.; Muc, Mugil cephalus; Lop, Lolliguncula panamensis; Hyp, Hyaloteuthis pelagica; Pen, Penaeus spp.; Xyp, Xyphopenaeus spp.; Cac, Caranx caballus; Laa, Larimus argenteus; Lug, Lutjanus guttatus; Lut $=$ Lutjanus spp.

Scomberomorus sierra (Jordan y Starks, 1895) (4.2), Thunnus albacares (Bonnaterre, 1788) (4.1) y Alectis ciliaris (Bloch, 1787) (4.0) (López-Peralta y Arcila 2002, Stergiou y Karpouzi 2002, Moreno-Sánchez et al. 2011, Tripp-Valdez et al. 2015, Froese y Pauly 2016, Alatorre-Ramirez et al. 2017), los cuales también se alimentaron de peces pelágicos que forman cardúmenes y de cefalópodos y crustáceos. Cabe señalar que la barracuda mexicana es parte del mismo gremio trófico e interactúa con estas especies en los ecosistemas del sur del golfo de California, lo que sugiere una posible competencia interespecífica. Sin embargo, parece que la disponibilidad y la abundancia de peces pelágicos pequeños que forman grandes cardúmenes (familias Engraulidae y Clupeidae) (TrippValdez et al. 2015, Varela et al. 2017, Zambrano-Zambrano et al. 2019), además de las diferencias morfológicas de los depredadores, permiten que estas especies coexistan sin afectar sus densidades poblacionales (Cruz-Escalona et al. 2000, Moreno-Sánchez et al. 2015).

Concluimos que la barracuda mexicana es un depredador ictiófago oportunista que no presenta diferencias en su dieta 
differences in its diet by sex or size, but it can change its preferred prey intake seasonally, depending the availability and abundance of its prey in the environment. This behavior, as stated in the optimal foraging theory, ensures optimization of the trade-off between consumption and energy use and, therefore, better bioenergetic performance.

\section{ACKNOWLEDGMENTS}

All of the authors are grateful for the economic support provided by the Secretaría de Investigación y Posgrado-IPN (project no. 20150852), Secretaría de Educación Pública-Consejo Nacional de Ciencia y Tecnología (CONACYT, Mexico) (project no. 241486), and CONACYT (project no. 205024). XGMS and LAAC are grateful for the support received through the IPN Comision de Operación y Fomento de Actividades Académicas and Estimulos al Desempeño de los Investigadores. OES thanks CONACYT for funding provided through the Cátedra CONACYT program, and FACIMAR-UAS. We appreciate the special collaboration of Dr. Emigdio Marín-Enríquez (CONACYT-FACIMAR-UAS), who helped with the statistical analysis, and the comments and suggestions of 2 anonymous reviewers. In memory of DSPS, an excellent researcher, colleague, and friend; rest in peace.

\section{Conflict of interest}

On behalf of all authors, the corresponding author states that there is no conflict of interest.

\section{REFERENCES}

Abitía-Cárdenas LA, Muhlia-Melo A, Cruz-Escalona V, GalvánMagaña F. 2002. Trophic dynamics and seasonal energetics of striped marlin Tetrapturus audax in the southern Gulf of California, Mexico. Fish Res. 57(3): 287-295. https://doi.org/10.1016/S0165-7836(01)00350-2

Alatorre-Ramirez VG, Galván-Magaña F, Torres-Rojas YE, Olson RJ. 2017. Trophic segregation of mixed schools of yellowfin tuna (Thunnus albacares) and skipjack tuna (Katsuwonus pelamis) caught in the eastern tropical Pacific Ocean. Fish. Bull. 115(2): 252-268.

https://doi.org/10.7755/FB.115.2.11

Amundsen PA, Gabler HM, Staldvik FJ. 1996. A new approach to graphical analysis of feeding strategy from stomach contents data-modification of the Costello (1990) method. J. Fish Biol. 48(4): 607-614.

https://doi.org/10.1111/j.1095-8649.1996.tb01455.x

Anderson MJ. 2006. Distance-based tests for homogeneity of multivariate dispersions. Biometrics 62: 245-253. https://doi.org/10.1111/j.1541-0420.2005.00440.x

Barreiros JP, Santos RS, Borba AE. 2002. Food habits, schooling and predatory behaviour of the yellowmouth barracuda, Sphyraena viridensis (Perciformes: Sphyraenidae) in the Azores. Cybium 26: 83-88.

Bedia-Sánchez C, Franco-López J, Barrera-Escorcia H. 2011. Análisis de la relación peso-longitud, alimentación y maduración gonádica de Sphyraena guachancho Cuvier, 1829 con respecto a sexo o talla, pero puede cambiar su consumo de presa preferente conforme la estación, dependiendo de la disponibilidad y abundancia de su presa en el ambiente. Este comportamiento, como lo indica la teoría del forrajeo óptimo, asegura la optimización de las compensaciones entre la ingesta y el uso de energía y, por lo tanto, un mejor rendimiento bioenergético.

\section{Agradecimientos}

Todos los autores agradecen el apoyo económico brindado por la Secretaría de Investigación y Posgrado-IPN (proyecto no. 20150852), la Secretaría de Educación Pública-Consejo Nacional de Ciencia y Tecnología (CONACYT, México) (proyecto no. 241486) y el CONACYT (proyecto no. 205024). XGMS y LAAC agradecen el apoyo recibido a través de la Comisión de Operación y Fomento de Actividades Académicas y Estímulos al Desempeño de los Investigadores del IPN. OES agradece al CONACYT por los fondos provistos a través del programa de Cátedra CONACYT y FACIMAR-UAS. Agradecemos la colaboración especial del Dr. Emigdio Marín-Enríquez (CONACYT-FACIMAR-UAS), quien ayudó con el análisis estadístico, y los comentarios y las sugerencias de 2 revisores anónimos. En memoria de DSPS, un excelente investigador, colega y amigo; descansa en paz.

\section{Conflicto de intereses}

En nombre de todos los autores, el autor de correspondencia declara que no hay conflicto de intereses.

Traducido al español por Claudia Michel-Villalobos

(Sphyraenidae) en Playa Barrancas, Municipio de Alvarado, Veracruz. Rev. Zool. 22: 23-32.

Brusca RC. 1980. Common Intertidal Invertebrates of the Gulf of California. 2nd ed. Tucson (AZ): University of Arizona Press; $513 \mathrm{pp}$.

Clothier CR. 1950. A key to some southern California fishes based on vertebral characters. Calif. Dep. Fish and Game Fish Bull. 79: $1-83$.

Colwell RK. 2009. EstimateS: Statistical Estimation of Species Richness and Shared Species from Samples. V.8.2. [Unknown]: [publisher unknown]; [accessed 2017 Jan 01]. http://viceroy.eeb. uconn.edu/estimates

[CONAGUA] Comisión Nacional del Agua (MX). 2013. Estadísticas del agua en México. Mexico City: CONAGUA; 165 pp.

Cortés E. 1997. A critical review of methods of studying fish feeding based on analysis of stomach contents: application to elasmobranch fishes. Can. J. Fish. Aquat. Sci. 54(3): 726-738. https://doi.org/10.1139/f96-316

Cortés E.1999. Standardized diet compositions and trophic levels of sharks. ICES J. Mar. Sci. 56(5): 707-717. https://doi.org/10.1006/jmsc.1999.0489 
Costello MJ. 1990. Predator feeding strategy and prey importance: a new graphical analysis. J. Fish Biol. 36 (2): 261-263. https://doi.org/10.1111/j.1095-8649.1990.tb05601.x

Cruz-Escalona VH, Abitia-Cardenas LA, Campos-Dávila L, Galvan-Magaña F. 2000. Trophic interrelations of the three most abundant fish species from Laguna San Ignacio, Baja California Sur, Mexico. Bull. Mar. Sci. 66(2): 361-373.

Daniel WW. 1997. Bioestadística: Base para el Análisis de las Ciencias de la Salud. Mexico: Limusao; 878 pp.

De Sylva DP. 1963. Systematics and Life History of the Great Barracuda Sphyraena barracuda (Walbaum). Coral Gables (FL): University of Miami Press; 179 pp.

Espino-Barr E, Cruz-Romero M, García-Boa A. 2003. Peces marinos con valor comercial de la costa de Colima, México. Manzanillo (Colima, Mexico): CONABIO E INAPESCA; $106 \mathrm{pp}$.

Fischer W, Krupp F, Schneider W, Sommer C, Carpenter KE, Niem VH. 1995a. Guía FAO para la Identificación de Especies para los Fines de Pesca, Pacífico Centro-Oriental. Vol. 2, Vertebrados: Parte 1. Rome (Italy): Food and Agriculture Organization of the United Nations; pp. 647-1200.

Fischer W, Krupp F, Schneider W, Sommer C, Carpenter KE, Niem VH. 1995b. Guía FAO para la Identificación de Especies para los Fines de Pesca, Pacífico Centro-Oriental. Vol. 3, Vertebrados: Parte 2. Rome (Italy): Food and Agriculture Organization of the United Nations; pp. 1201-1813.

Froese R, Pauly D, editors. 2016. FishBase: World Wide Web electronic publication; [accessed 2017 March 10]. http://www. fishbase.org.

Gerking SD. 1994. Feeding Ecology of Fish. USA: Academic Press; $416 \mathrm{pp}$. https://doi.org/10.1016/c2009-0-03283-8

Hacunda JS. 1981. Trophic relationships among demersal fishes in a coastal area of the Gulf of Maine. Fish. Bull. 79(4): 775-788.

Hooker HB, Castro-González E, Howard AA, Quintero JA, Sanabria MP. 2007. Hábitos tróficos de la Gran Barracuda, Sphyraena barracuda (Walbaum, 1792) (Pisces: Perciformes: Sphyraenidae) en la Isla de San Andrés, Cayos Bolívar y Albuquerque, Reserva de la Biosfera Sea Flower $=$ Food Habits of the Great Barricuda, Sphyraena barracuda (Walbaum, 1792) (Pisces: Perciformes: Sphyraenidae) on the Islands of San Andres, Cayos Bolivar, and Albuquerque Sea Flower BioReserve, Colombia. Proc. Gulf Caribb. Fish. Inst. 58: 208-215.

Hurlbert SH. 1978. The measurement of niche overlap and some relatives. Ecology 59(1): 67-77. https://doi.org/10.2307/1936632

Hyslop EJ. 1980. Stomach contents analysis - a review of methods and their application. J. Fish Biol. 17(4): 411-429. https://doi.org/10.1111/j.1095-8649.1980.tb02775.x

Jiménez-Valverde A, Hortal J. 2003. Las curvas de acumulación de especies y la necesidad de evaluar la calidad de los inventarios biológicos. Rev. Iber. Aracnol. 8(31): 151-161.

Kalogirou S, Mittermayer F, Pihl L, Wennhage H. 2012. Feeding ecology of indigenous and non-indigenous fish species within the family Sphyraenidae. J. Fish. Biol. 80(7): 2528-2548. https://doi.org/10.1111/j.1095-8649.2012.03306.x

Krebs CJ. 1999. Ecological Methodology. Menlo Park (CA): Addison-Wesley Educational Publishers; 620 pp.

López-García J, Navia AF, Mejía-Falla PA, Rubio EA. 2012. Feeding habits and trophic ecology of Dasyatis longa (Elasmobranchii: Myliobatiformes): sexual, temporal and ontogenetic effects. J. Fish. Biol. 80(5): 1563-1579. https://doi.org/10.1111/j.1095-8649.2012.03239.x
López-Peralta RH, Arcila CAT. 2002. Diet composition of fish species from the southern continental shelf of Colombia. Naga, World Fish Center Quarterly 25(3-4): 22-29.

Miller GL, Jorgenson SC. 1973. Meristic characters of some marine fishes of the western Atlantic Ocean. Calif. Dep. Fish and Game Fish Bull. 71: 301-312.

Mohammadizadeh F, Valinassab T, Jamili S, Matinfar A. 2010. A study on diet composition and feeding habitats of sawtooth barracuda (Sphyraena putnamae) in Bandar-Abbas (North of Persian Gulf). J. fish. Aquat. Sci. 5(3): 179-190. https://doi.org/10.3923/jfas.2010.179.190

Moreno-Sánchez XG, Palacios-Salgado DS, Abitia-Cárdenas LA, Nieto-Navarro JT, Navia FA. 2015. Diet of the yellowfin snook, Centropomus robalito (Actinopterygii: Perciformes: Centropomidae), in the southwestern Gulf of California. Acta. Ichthyol. Piscat. 45(1): 21-29. https://doi.org/10.3750/AIP2015.45.1.03

Moreno-Sánchez XG, Quiñonez-Velázquez C, Abitia-Cárdenas LA, Rodríguez-Romero J. 2011. Diet of the Pacific sierra Scomberomorus sierra (Perciformes: Scombridae) in two areas of north-west Mexico coast. Aqua Int. J. Ichthyol. 17(4): 185-192.

Morris RH, Abbott DP, Haderlie EC. 1980. Intertidal Invertebrates of California. Stanford (CA): Stanford University Press; 690 pp.

Nelson JS, Grande TC, Wilson MVH. 2016. Fishes of the world. 5th Ed. Hoboken (NJ): John Wiley and Sons; 707 pp.

Oksanen J, Blanchet FG, Friendly M, Kindt R, Legendre P, McGlinn D, Minchin PR, O'Hara RB, Simpson GL, Solymos P, et al. 2016. Vegan: Community Ecology Package. v.2.4-1: $\mathrm{R}$ documentation. [Unknown]: [publisher unknown]; [accessed 2019 Feb 14] http://CRAN.R-project.org/ package $=$ vegan

Pauly D, Christensen V. 2000. Trophic ecology. In: Froese R, Pauly D (eds.), FishBase 2000: Concepts, design and data sources. Makati City (Philippines): International Center for Living Aquatic Resource Management; 344 pp.

Pinkas L, Oliphant MS, Iverson LK. 1971. Food habits of albacore, bluefin tuna, and bonito in California waters. Calif. Dep. Fish and Game Fish Bull. 152: 1-105.

R Core Team. 2016. R: A language and environment for statistical computing. Vienna (Austria): R Foundation for Statistical Computing. https://www.R-project.org/

Robertson DR, Allen GR. 2015. Shore fishes of the Tropical Eastern Pacific: online information system. v.2.0. Balboa (Panama): Smithsonian Tropical Research Institute; [accessed 2017 January 10]. http://biogeodb.stri.si.edu/sftep/en/pages

Sommer C. 1995. Sphyraenidae. Barracudas, picudas. In: Fischer W, Krupp F, Schneider W, Sommer C, Carpenter KE, Niem V. (eds.), Guia FAO para identificacion de especies para los fines de la pesca. Pacífico Centro-Oriental. Vol. 3, Vertebrados: Parte 2. Roma (Italia): Food and Agriculture Organization of the United Nations; pp. 1618-1621.

Stergiou KI, Karpouzi VS. 2002. Feeding habits and trophic levels of Mediterranean fish. Rev. Fish Biol. Fisher. 11(3): 217-254. https://doi.org/10.1023/A\%3A1020556722822

Tripp-Valdez A, Galván-Magaña F, Ortega-García S. 2015. Food sources of common dolphinfish (Coryphaena hippurus) based on stomach content and stable isotopes analyses. J. Mar. Biol. Assoc. UK. 95(3): 579-591. http://dx.doi.org/10.1017/S0025315414001842

Ulloa-Ramírez PA, Patiño-Valencia JL, Guevara-Rascado ML, Hernández-Ventura S, Sánchez-Regalado R, Pérez-Velázquez A. 2008. Peces marinos de valor comercial del estado de Nayarit, México. Bahía de Banderas (Nayarit, México): Instituto Nacional de Pesca; 91 pp. 
Varela JL, Lucas-Pilozo CR, González-Duarte MM. 2017. Diet of common dolphinfish (Coryphaena hippurus) in the Pacific coast of Ecuador. J. Mar. Biol. Assoc. UK. 97(1): 207-213.

https://doi.org/10.1017/S0025315416000175

Wootton RJ. 1998. Ecology of teleost fishes. 2nd Ed. Dordrecht (Holland): Kluwer Academic Publishers; 386 pp.

Zambrano-Zambrano RW, Mendoza-Moreira PE, Gómez-Zamora W, Varela JL. 2019. Feeding ecology and consumption rate of broadbill swordfish (Xiphias gladius) in Ecuadorian waters. Mar. Biodiv. 49(1): 373-380.

https://doi.org/10.1007/s12526-017-0814-0

Zavala-Leal I, Palacios-Salgado DS, Ruiz-Velazco JMJ, ValdezGonzález F, Pacheco-Vega JM, Granados-Amores J, FloresOrtega JR. 2018. Reproductive aspects of Sphyraena ensis (Perciformes: Sphyraenidae) inhabiting the coast of San Blas Nayarit, southeast Gulf of California. Calif. Fish and Game 104(1): 7-18.

Received February 2019, accepted June 2019. 